\title{
Spontaneus Resolution of a Traumatic Vertebral Artery Pseudoaneurysm
}

\author{
Travmatik Vertebral Arter Psödoanevrizmasının Kendiliğinden \\ İyileşmesi
}

\author{
Ayhan TEKINER, Cevdet GOKCEK, Mehmet Akif BAYAR, Yavuz ERDEM, Celal KILIC \\ Ministry of Health, Ankara Training and Research Hospital, Department of Neurosurgery, Ankara, Turkey \\ Presented in: 22 th Annual Scientific Congress of Turkish Neurosurgical Society, 18-22 April 2008, Antalya, Turkey
}

Correspondence address: Ayhan TEKINER / E-mail: tekinerayhan@hotmail.com

\begin{abstract}
Injuries of the vertebral artery are rare and are usually seen after penetrating or blunt cervical trauma. Vertebral artery injuries (VAl) have been reported in $0.5 \%$ of blunt trauma cases. These injuries can lead to hemorrhage, thrombosis, arteriovenous fistula or traumatic pseudoaneurysm in the early or late period. They must be treated carefully due to their increased risk of morbidity and mortality. In this case report, we present a case of asymptomatic traumatic vertebral artery pseudoaneurysm(TVAP) seen after cervical spinal trauma with C5-C6 listhesis developing afterwards, treated with anterior-posterior stabilization and fusion. Spontaneous resolution of the pseudoaneurysm is demonstrated by vertebral arter angiogrphy.
\end{abstract}

KEYWORDS: Cervical trauma, Traumatic pseudoaneurysm, Vertebral artery

öz

Klivus kordomaları sıklıkla orta hat lezyonlarıdır. Kafa tabanı kordomalarının kritik lokalizasyonu, invaziv yapısı ve sık nüks eden lezyonlar olması nedeniyle cerrahi tedavileri zorlayıcıdır. Bu bildiride pediküllü transnazal, transfasial yaklaşımla ameliyat edilen bir olgu sunuldu. Olgu kranial sinir paralizisi ve beyin sapı bası bulguları ile başvurdu. Lezyon herhangi bir nörolojik defisit olmaksızın çıkarıldı. Ameliyattan sonra olgunun beyin sapı bası bulguları geriledi. Olgumuzda lateral nazal insizyonla geniş bir cerrahi alan sağlanarak total tümör eksizyonu ile beraber kozmetik olarak da kabul edilir bir sonuç alınmıştır ve postoperatif takibinde uygulanan cerrahi prosedürün başarılı olduğu görülmüştür.

ANAHTAR SÖZCÜKLER: Servikal travma, Travmatik psödoanevrizma, Vertebral arter

\section{INTRODUCTION}

Injuries of the vertebral artery are rare and are usually seen after penetrating or blunt cervical trauma. Vertebral artery injuries have been reported in $0.5 \%$ of blunt trauma cases (19). These injuries can lead to hemorrhage, thrombosis, arteriovenous fistula or traumatic pseudoaneurysm in the early or late period $(1,19)$. A true aneurysm is designated when the vessel wall contains intact intima, media, and adventitia. A false or pseudoaneurysm is designated when the endothelial lining and other vessel wall components are disrupted and the enlarged contour is maintained by the adjacent soft tissues, a fibrous capsule, or both (14). A pseudoaneurysm can be asymptomatic, or lead to neurological symptoms such as vertigo, tinnitus and ataxia or cranial nerve symptoms, spinal nerve symptoms or spinal cord symptoms by local mass effect (6). The natural evolution of these pseudoaneurysms is not well known $(1,10,19)$. Nevertheless these pseudoaneurysms must be treated carefully due to their increased risk of morbidity and mortality. Choice of treatment, such as surgery or endovascular methods, directly depends on the dimensions and localization of the pseudoaneurysm $(1,2,5,6,10,19)$.

In this case report, we present an asymptomatic traumatic vertebral artery pseudoaneurysm (TVAP) seen after cervical spinal trauma with C5-C6 listhesis developing afterwards, treated with anterior-posterior stabilization and fusion. Spontaneous resolution of the pseudoaneurysm was demonstrated by angiography.

\section{CASE REPORT}

A 65-year-old woman was referred to our clinic after an in-car traffic accident with whiplash trauma. She complained of neck pain and limited neck movements. No neurological deficit was observed. Radiological examination with routine radiography cervical region revealed listhesis at the fifth and sixth cervical vertebrae (Figure 1). T1-weighted axial MRI findings displayed "signal void" consistent with right vertebral arterial flow. The left vertebral artery was hypoplasic and patent (Figure 2). Digital subtraction angiography (DSA) of the patient 
revealed an pseudoaneurysm $3 \mathrm{~mm}$ in diameter originating from the right vertebral artery at the level of the third cervical vertebra (Figure 3). Other radiological examinations led to a diagnosis of listhesis at the fifth and sixth cervical vertebrae and the patient went on to surgery. Anterior and posterior stabilization and fusion were performed on the fifth and sixth cervical vertebrae. Endovascular treatment was planned for the vertebral artery pseudoaneurysm but the procedure was not accepted by the patient. The patient presented at our clinic 2 years later and no pathological findings were detected on physical examination. DSA showed no abnormal findings and there was no evidence of the right vertebral artery pseudoaneurysm seen in the DSA taken 2 years previously (Figure 4)

\section{DISCUSSION}

Few studies have focused on vertebral artery injury (VAI) following blunt trauma until recently, so it is difficult to estimate its true incidence (8). Many cases of blunt vertebral injury (BVI) likely remain asymptomatic or result in subtle neurological deficits that go undetected. BVIs are therefore underdiagnosed without aggressive diagnostic screening, (8).

Cervical spine injury appears to have a specific association with BVI. High-speed motor vehicle crashes and falls account for the majority of cervical spine fractures and may account for the majority of VAI cases as well. Although BVI was initially thought to occur principally with upper cervical fractures, angiographic screening of cervical fractures has documented a significant coincidence of BVI with all types of spinal injuries such as $40 \%$ of lateral dislocations (16), $46 \%$ of midcervical

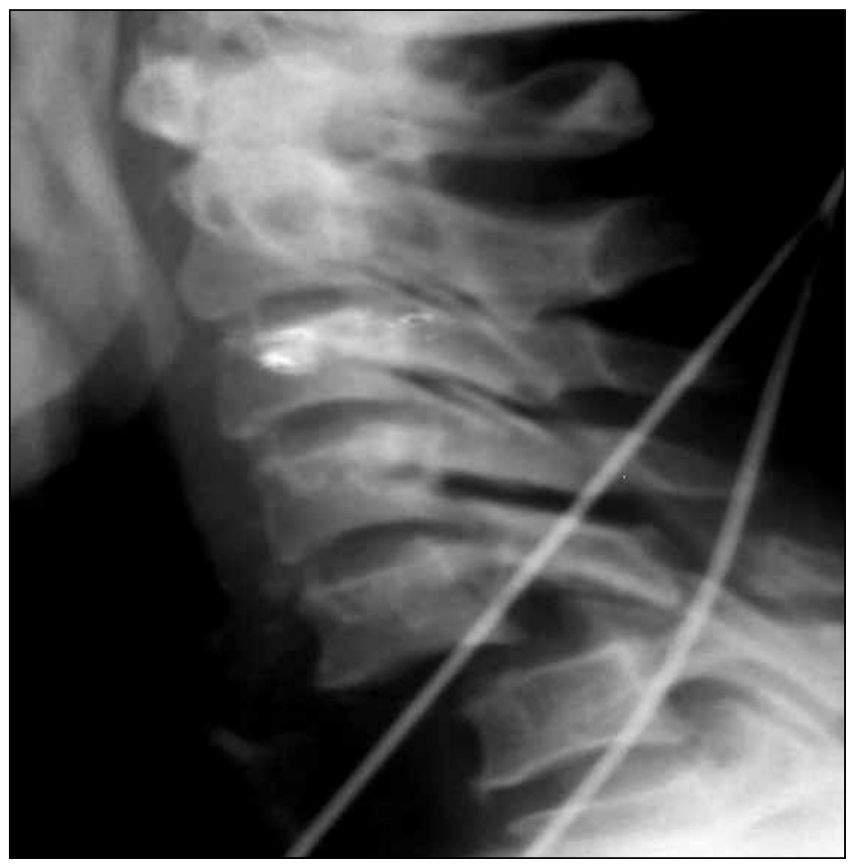

Figure 1: Radiographic appearance of the patient prior to surgery. fractures with facet injury (23), and $88 \%$ of fractures involving the foramen transversarium (24).

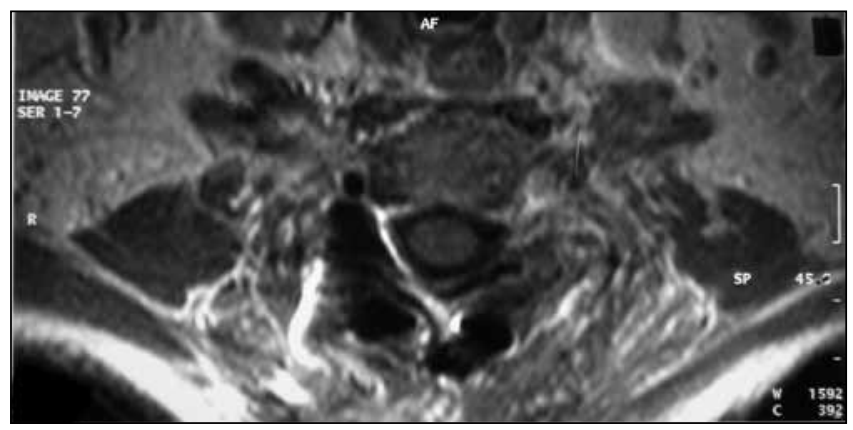

Figure 2: T1-weighted axial MRI findings display "signal void" consistent with right vertebral arterial flow. The left vertebral artery is hypoplasic and patent.

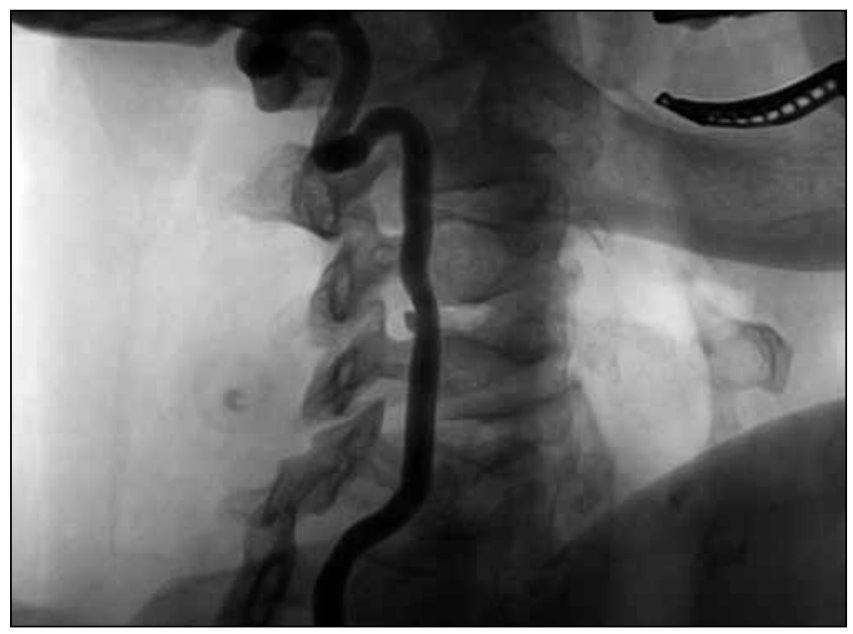

Figure 3: Digital subtraction angiography (DSA) of the patient showing a right vertebral artery pseudoaneurysm $3 \mathrm{~mm}$ in diameter originating from the level of the third cervical vertebra (arrowhead).

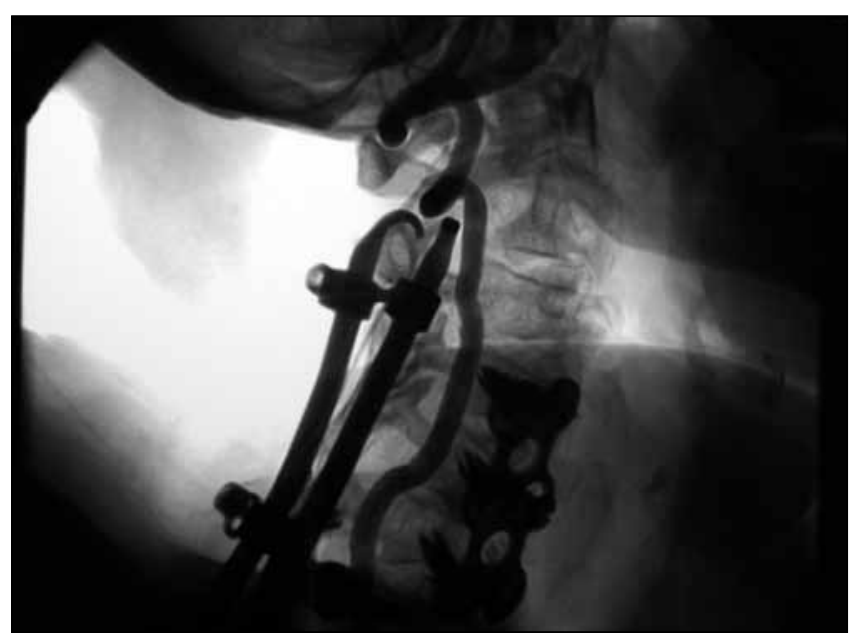

Figure 4: DSA taken at the 2-year follow-up after the injury showing spontaneous resolution of the pseudoaneurysm. 
The vertebral artery (VA) is divided into 4 anatomic sections (1, $5,19)$. The first section starts from the origin at the subclavian artery and reaches to the level of the transverse foramen of the sixth cervical vertebra. The second section of the vertebral artery runs between the sixth and first cervical vertebra in the transverse foramens. The third and fourth sections continue after the artery leaves the transverse foramen of the first cervical vertebra and joins with the vertebral artery of the opposite side to form the basilar artery in the cranium.

The first portion of the VA is rarely injured from blunt trauma, possibly owing to its mobility and lack of any surrounding bone. However, the second portion of the VA, which ascends through the transverse foramina of the upper six cervical vertebrae, is frequently injured when cervical fractures involve the foramen $(23,24)$. The third portion of the VA curves posteriorly behind the lateral mass of the atlas and lies in the groove on the upper surface of the posterior arch of the atlas. Because of the high frequency of cervical fractures and ligamentous injuries in this region, as well as stretching and compression at the atlantoaxial and atlanto-occipital joints during head rotation, this segment of the VA extending from C2 to the dura is particularly prone to injury during blunt trauma $(11,13)$.

AlthoughTVAP cases have increased in recentyears, it is defined as a rare lesion in the literature $(1,2,5,6,10,12,19)$. TVAP is seen mostly after blunt or penetrating cervical trauma $(1,10$, 12). TVAP can also be seen after chiropractic manipulation or cervical implant dislocation and in rheumatoid arthritis (7, 9). TVAP is rarely seen as a result of the anatomic position of the vertebral artery and its natural position within the bones (1). Schittek (19) has studied 144 VA injury reports printed in English and found 27 TVAP cases in these reports. Nearly half of these pseudoaneurysms originated from the second section of the VA. The case reports published afterwards also state that the pseudoaneurysm usually originates from the second section of the VA $(1,10,12)$. The TVAP presented in our case also originated from the second section. Pseudoaneurysms originating from the second segment of the VA are seen relatively more frequently due to the higher risk of VA trauma in this region.

Symptoms and findings of TVAP vary according to the size and localization of the pseudoaneurysm. Some cases can be asymptomatic and determined incidentally as in our case. Some symptoms could be related to the mass effect of the pseudoaneurysm in half of the cases (18). These symptoms can occur due to compression of cranial nerves, cervical spinal nerves, brachial plexus or spinal cord $(1,5,18,19)$. In addition vertebrobasilar insufficiency symptoms like vertigo and ataxia can occur as a result of thromboembolism $(1,18)$. Furthermore, TVAP's destructing the cranial bones with their increasing size have also been reported (21).

The natural evolution of TVAP is not well known. Some cases with spontaneous resolution as in the case we presented have been published before $(5,10,19)$. The diagnosis, treatment and follow-up of these cases is very important as stroke and mortality were observed in $13 \%$ of the published TVAP cases $(2,3,12,15,19)$. The most important point in the diagnosis of TVAP is being aware of the possibility after all blunt or penetrating cervical trauma. Magnetic resonance angiography (MRA), computed tomography angiography (CTA) or DSA, if needed, are helpful in diagnosis after such injuries. These lesions must be treated carefully due to the potential morbidity and mortality $(3,4,15)$. These pseudoaneurysms can be treated with a direct surgical approach, proximal vertebral artery ligation or an endovascular approach (coil embolization, stent-supported coil embolization) $(1,2,5$, 18 , 19). Blickenstaff (5) reported that proximal ligation is adequate and that there is no need for the recommended proximal and distal ligation. Neurological complications have been reported at a rate of $8 \%$ after unilateral VA ligation (22). Reid (17) reported no neurological deficit in cases treated with unilateral VA ligation. However the amount of data on cerebral blood flow after vertebrobasilar system test occlusion and the clinical consequences is inadequate. There is a high risk of neurological deficit after ligation, especially when the contralateral vertebral artery blood flow is insufficient. Endovascular procedures are mostly preferred today as they preserve blood flow, are less traumatic and surgeons have increasing experience with them $(2,5,15,19)$. On the other hand, recurrence after coil embolization has also been reported $(2,15)$.

Conclusion: TVAP can develop after any blunt or penetrating cervical trauma with vertebral fractures-dislocation involving the transverse foramina and basilar skull fractures. Every patient with this condition should be evaluated for VAI. MRA, CTA and DSA, if required, provide enough information for the diagnosis. The natural evolution of TVAP is not well known. Spontaneous resolution of these lesions is rare. TVAPs have potential morbidity and mortality risks. They must therefore be carefully treated surgically or with endovascular procedures.

\section{REFERENCES}

1. Anand VK, Raila FA, Mc Avley SR, Reed JM: Giant pseudoaneurysm of the extracranial vertical artery. Otolaryngol Head Neck Surg 109(6):1057-1060,1993

2. Ashley WW, Rivet D, Cross DT, Santiago P: Development of a giant cervical vertebral artery pseudoaneurysm after a traumatic C1 fracture: Case illustration Surg Neurol 66(1):80-81, 2006

3. Biffl WL, Moore EE, Eliot JP: The devastating potential of blunt vertebral arterial injuries. Ann Surg 231:672-681, 2000

4. Biff WL, Moore EE, Offner PJ: Blunt carotid and vertebral arterial injuries. World J Surg 25(8):1036-1043, 2001

5. Blickenstaff KL, Weaver FA, Yellin AE, Stain SC, Finck E: Trends in the management of traumatic vertebral artery injuries. Neurosurgery 138:101-105, 1989

6. Detwiler K, Godersky SC, Gentry L: Pseudoaneurysm of the extracranial vertebral artery. Case report. J Neurosurg 67(6): 935-939, 1987

7. Early CB, Shuring AG, Hunt WE: False Pseudoaneurysm of the vertebral artery-a complication of radon seed implantation: Case report and merit of anterolateral approach. Ann Surg 164: 900-902, 1966 
8. Elliott JP, Newel DV: Traumatic cerebrovascular injury: Neurological Surgery Youmans Fifth Edition, Vol IV, Chapter 330, 5205-5206, 2004

9. Fedele FA, Ho G Jr, Dorman BA: Pseudoaneurysm of the vertebral artery: A complication of rheumatoid cervical spine disease. Arthritis Rheum 29: 136-141, 1986

10. Hiatt JR, Martin HA, Machleder HI: The natural history of a traumatic vertebral artery pseudoaneurysm: Case Report J Trauma 29(11):1592-1594, 1989

11. Hinse P, Thie A, Lachenmayer L: Dissection of the extracranialvertebral artery: Report of four cases and review of the literature. J Neurol Neurosurg Psychiatry 54: 868-869, 1991

12. Islamoglu F, Pasacioglu H, Memiş A, Durmaz I: Endovascular transcatheter occlusion for traumatic vertebral artery pseudoaneurysm Eur J Vasc Endovasc Surg 20(6): 576-578, 2000

13. Josien E: Extracranial vertebral artery dissection: Nine cases. J Neurol 239: 327-330, 1992

14. Leiner T, Hellinger GC, Rossky NM: Upper extremity vascularity. Part III Chapter 22. CT and MR Angiography 1100, 2009

15. Mac Kay Cl, Han PP, Albuquerque FC: Recurrence of a vertebral artery dissecting pseudoaneurysm after successful stentsupported coil embolization: Case report Neurosurgery 53: 754-759, 2003
16. Parent AD, Harkey $H L$, Touchstone DA: Lateral servical spine dislocation and vertebral artery injury. Neurosurgery 31: 501-509,1992

17. Reid JDS, Weigelt JA: Forty-three cases of vertebral artery trauma J Trauma 28:1007-1012, 1988

18. Reyes RA, Maser FG, Sachs DP, Boehm FH: Direct repair of an extracranial vertebral artery pseudoaneurysm: Case report and review of the literature Neurosurgery 26: 528-533, 1990

19. Schittek A: Pseudoaneurysm of the vertebral artery. Case report. Tex Heart Inst J 26(1):90-95, 1999

20. Showalter W, Esekogwu V, Newton KI: Vertebral artery dissection. Acad Emerg Med 4: 991-995, 1997

21. Sumimura J, Nakao K, Maiyata M: Vertebral pseudoaneurysm of the neck. J Cardiovasc Surg 29:63-65, 1998

22. Wiener I, Flye MW: Traumatic false pseudoaneurysm of the vertebral artery. J Trauma 24:346-349, 1984

23. Willis BK, Greiner F, Orrison WW:The incidence of vertebral artery injury after midservical spine fracture or subluxation. Neuro surgery 34:435-442, 1994

24. Woodring JH, Lee C, Duncan V: Transverse process fractures of the cervical vertebrae: Are they insignificant? J Trauma 34: 797-802, 1993 